FACTA UNIVERSITATIS

Series: Visual Arts and Music Vol. 5, No 2, 2019, pp. 91 - 104

https://doi.org/10.22190/FUVAM1902091J

Original scientific paper

\title{
COMPARATIVE ANALYSIS OF THE CURRICULUM FOR THE SUBJECT SOLFEGGIO (EMS) IN SLOVENIA, MONTENEGRO, CROATIA AND SERBIA
}

\author{
UDC 371.3:784.9
}

\section{Milica Jovanović, Jelena Cvetković Crvenica}

University of Niš, Faculty of Arts in Niš, Republic of Serbia

\begin{abstract}
The paper deals with the comparison of curricula for the subject of Solfeggio in Serbia and several selected countries. On the basis of existing data, we compared the organization of Solfeggio teaching in Serbia and other countries of the region. The curriculum was analyzed in terms of structure, goals and subject content, teaching methods and evaluation of student achievement. The presentation and analysis of the curricula highlighted their (in)consistences, advantages and disadvantages, as well as indications of future development in the form of modernization of some curriculum areas modeled on other countries.
\end{abstract}

Key words: solfeggio, teaching, music pedagogy, curriculum.

\section{INTRODUCTION}

Since it covers the essential elements of musicality, the Solfeggio subject has a prominent place in the context of professional music education and the formation of a complete musical personality. As such, it is represented at all stages of music education and is the basis for acquiring intonative and rhythmic knowledge and skills that facilitates the understanding of music. The development of musical abilities, the understanding of musical content and the performance of music is achieved through a series of teaching elements within the teaching of Solfeggio. In this regard, the beginning, course and outcomes of the realization of an individual's musical potential can only be determined by a carefully designed teaching process (Cvetković-Crvenica and Jovanović, 2018).

For the last fifteen years, the Serbian school system, like the school systems of neighboring countries, has been undergoing a process of thorough restructuring and reorganization. The directions of its development refer to the successful implementation

Received October 2019 / Accepted November 2019

Corresponding author: Milica Jovanović

University of Niš, Faculty of Arts in Niš

E-mail: milica.jovanovic37@yahoo.com 
of planned changes in teaching (Hebib and Spasenović, 2011). Educational changes are equally affecting the teaching process of professional music education, which is increasingly focused on providing high quality knowledge for the students. In an effort to improve the quality of education, learning is increasingly reflected in developing a way of thinking musically, not just in acquiring skills. Providing quality and productive teaching imposes the need for professionally, pedagogically and psychologically competent teaching staff, that is, implementers of teaching content and those who will encourage students on a long path of musical hearing development, whereby the acquisition of quality teaching competences is profiled through a lifelong learning and training process (Pavić, 2017). Initial education provides an individual with sufficient music expertise but cannot prepare him or her for all the challenges of teaching. Therefore lifelong training for music school teachers is an indispensable part of their professional development. Teachers' competences, with mastery of intonation methods, should be extended to the use of digital tools and the realization of team and interdisciplinary teaching, so that Solfeggio can be meaningfully connected with other fields of music education (Matoš, 2018). Putting the focus of modern education on student-centered teaching and learning outcomes influences the whole teaching process, and one of the factors in the function of raising the quality of teaching is certainly innovation (Cvetković-Crvenica, 2017).

The successful process of music (and general) education depends to a large extent on the systematic monitoring and identification of the quality of the curriculum. The transition to a curricular approach is considered to be a good way of adapting the education system to the demands of time and providing space for continuous improvement and development of the education system (Aleksendrić, 2009), so interest in this topic has arisen precisely from placing curriculum issues at the center of the educational policy.

\section{CURRICULUM}

The term curriculum ${ }^{1}$ is introduced into the educational process at the turn of the 16 th to the 17th century with the advent of refinement of content, which is transmitted to students at certain times and in a certain order. The 1950s saw the separation of European and American understandings of the curriculum, which today still influence the definition and demarcation of the two. In the 1970s and 1980s, interest in the curriculum diminished and only after the 1980s did methodological curriculum development begin, with the study of curriculum being expanded to explore the conditions under which learning and teaching were conducted and curriculum consideration, its structures, designs and applications are increasingly dominated by the scientific approach that is being advanced today (Previšić, 2007).

Differences in philosophical approaches and understanding of the character and function of education and learning are reflected in the different definition and understanding of the curriculum, so the curriculum is understood as: the content of learning, the product of learning, the plan of learning and the learning experience (Pekeč, 2011). Individual authors (Sučević and Srdić, 2012) refer to the term curriculum as the overall flow of education. What sets curriculum apart from traditional education programs is control, that is, the multiplicity of

${ }^{1}$ Currere (lat.) - run, run race, race, etc. Transferred to the field of education and learning, the term curriculum, in its original form, meant the course and sequence of learning, a series of obstacles and obstacles (learning) to be learned over time. 
monitoring and feedback on learning outcomes, so the definition of curriculum can be formulated more extensively, given that it involves extensive planning, organization and verification of work processes and actions in accordance with appropriate detailed goals, content elements, and control (evaluation) of achievement against globally set goals and settings for the teaching process (Jurić, 2005). Nowadays, in most European countries, the term curriculum encompasses goals, content, situations, strategies and evaluation issues (Matijević, 2010).

There are three basic types of curriculum in the literature: closed, open and mixed curricula. The closed curriculum equates to the traditional understanding of the curriculum and, here, everything is prescribed so that it does not leave much room for spontaneity and creativity, indispensable factors of contemporary pedagogy. The open curriculum, instead of strict regulations, offers only curriculum guidelines and provides a freer approach that the closed curriculum neglects. Nowadays, a mixed curriculum is most commonly implemented, which combines the positive characteristics of a closed and open curriculum and makes a kind of compromise between the two types (Previšić, 2007).

The aim of this paper is to define the status of the Solfeggio subject in the curricula of neighboring countries - Slovenia, Montenegro and Croatia - in comparison with the Serbian education system and the Solfeggio teaching within it. A common starting point is the fact that the Solfeggio subject is a compulsory subject in the selected countries. Changes in the state system after the breakup of the former SFRY have also led to changes in the education systems. Emerging states were confronted with different concepts and proposals for reforming the school system, which led to the adoption of different regulatory solutions and the formation of separate curricula that had been identical until then.

The comparative interpretation of the curricula of these countries aims to provide answers to questions that are directly related to the different concepts of Solfeggio teaching. Using a descriptive document content analysis method, the content and structure, as well as the complementarity of current curricula, will be analyzed and compared throughout the presentation:

1) Organization of Solfeggio teaching

2) The aims and tasks of Solfeggio teaching

3) Teaching elements

4) Methods

5) Student achievement evaluation

The analysis should contribute to the acquisition of a deeper understanding of the musical educational structure of the countries we have mentioned, which provides the basis for further research in the area.

\section{Curriculum Review For SolfegGio SubJect In the Selected Countries}

\subsection{Organization of Solfeggio teaching}

Solfeggio teaching is a compulsory subject in all analyzed countries. Teaching is in groups, so it includes all elements of socialization, but from a musical standpoint it requires adjusting one's own musicality to the group.

The program of music education in Slovenian elementary music schools is conceptualized in two levels: lower (4 to 6 years) and higher ( 2 years), while the concept of Solfeggio in the curriculum of Slovenia itself has a double meaning (Zadnik, 2019). 
This term refers to the title of the subject at the upper level of the music school and the independent area of music activity within the subject of Music (Nauk o glasbi). Nauk o glasbi is taught by students in grades 1 through 6 , and Solfeggio by students in grades 7 and 8. Classes are taught once a week for 60 or 90 minutes, or twice a week for 45 minutes, depending on the number of students in the group. ${ }^{2}$

With the reform of the education system in Montenegro, the duration of the general education school was extended from six to nine years, which resulted in the transition from six years to nine years of music school. ${ }^{3}$ Students enroll in a music school, ie, the first grade of Music Preparation (Musical Beginner - Orf Instrumentary) at the age of 6, after which they transfer to the second grade, begin to learn an instrument of their choice and attend a course called Solfeggio with music theory (Solfeđo sa teorijom muzike). After a cycle of 6 years, highly talented students continue the third three-year cycle, as potential candidates for further music education at the high school level. The course is divided into three cycles of three years each.

- The first cycle (grade I-III) contains elementary music literacy. Develops in students an interest in music, musicality and a sense of rhythm.

- The second cycle (grades IV-VI) contains more advanced music literacy. Develops the precision of intonative and rhythmic performance as well as other musical skills.

- The third cycle (grades VII-IX) contains advanced music literacy. Develops harmonic hearing, the student applies acquired knowledge in creative music activities, uses adequate musical terminology to describe a piece of music preparing students for the next level of music education.

Solfeggio with music theory starting from the second grade is performed once a week for 45 minutes, while from the 3 rd to the 9 th grade this subject takes place twice a week for 45 minutes. 4

Elementary music school education in Croatia, unlike Slovenia and Montenegro, lasts for six years in all subjects and courses. The school can enroll children who have reached the age of seven after meeting the criteria stipulated in the curriculum of art education, ie, after they passed the entrance examination. Group Solfeggio classes take place twice a week for 45 minutes. ${ }^{5}$

By the Rulebook on the Curriculum of Elementary Music School Education of Serbia, the entire education is realized in two educational cycles of six, four or two years. In the first grade of primary music school a student may enroll for a period of six years under the age of nine, for a period of four years - under the age of eleven and for a period of two years - over fourteen years old. A group in the Solfeggio teaching classes can have a maximum of 10 students. Classes last 45 minutes, and are held at an interval of two classes per week from the first to the sixth or, respectively the fourth (for a four-year

\footnotetext{
${ }^{2}$ Učni načrt, subject Nauk o glasbi:

http://www.mizs.gov.si/fileadmin/mizs.gov.si/pageuploads/podrocje/glasba/pdf/nauk_o_glasbi321-340.pdf Učni načrt, subject Solfeggio:

http://www.mizs.gov.si/fileadmin/mizs.gov.si/pageuploads/podrocje/glasba/pdf/solfeggio341-348.pdf

${ }^{3}$ Službeni list Republike Crne Gore, br 64/2002, 49/2007, Sl. list CG, br. 45/2010, 40/2011 - dr. zakon i 39/2013. "Zakon o osnovnom obrazovanju i vaspitanju u Crnoj Gori."

${ }^{4}$ Zavod za školstvo, Predmetni program Solfeđo sa teorijom muzike II, III, IV, V, VI, VII, VIII i IX razred devetogodišnje osnovne muzičke škole, Crna gora, Podgorica :

http://www.zzs.gov.me/naslovna/programi/muzicke_skole/

${ }^{5}$ Nastavni planovi i program za osnovne glazbene i osnovne plesne škole, 2006: http://www.gsjh.hr/wpcontent/ uploads/2017/12/Nastavni_PP_predskolskog_i_osnovnog_obrazovanja_za_glazbene_i_plesne_skole.pdf
} 
education and upbringing) grade. The exception is the first cycle (1st grade) of the school for two years' education, where classes are held at an interval of three classes per week, that is, 105 hours per year. ${ }^{6}$

Based on the data of the analyzed curricula, differences were found in terms of subject name, length and time of study, as well as slight differences in the number of weekly classes (Table 1). Harmonizing the duration of general education and music school seems a logical and desirable step to consider in our education system, with the aim of continuously developing students' musical abilities, in order to avoid the loss of student motivation during class re-enrollment due to uneven programs.

Table 1 Organization of Solfeggio teaching

\begin{tabular}{|c|c|c|c|c|}
\hline$\overline{\text { Country }}$ & Name of the subject & $\begin{array}{l}\text { Length } \\
\text { of study }\end{array}$ & Subject status & Time of study \\
\hline Slovenia & $\begin{array}{l}\text { Music - Nauk o glasbi } \\
\text { (lower level) } \\
\text { Solfeggio } \\
\text { (upper level) }\end{array}$ & 8 years & Compulsory & $\begin{array}{l}\text { - Once a week } \\
\text { ( } 60 \text { or } 90 \text { minutes) or } \\
\text { - Twice a week } \\
\text { (45 minutes) }\end{array}$ \\
\hline Montenegro & $\begin{array}{l}\text { Solfeggio with theory of music } \\
\text { (Solfeđo sa teorijom muzike) }\end{array}$ & 8 years & Compulsory & $\begin{array}{l}\text { - In } 2^{\text {nd }} \text { grade once a } \\
\text { week ( } 45 \text { minutes) } \\
\text { - from } 3^{\text {rd }} \text { to } 9^{\text {th }} \text { grade } \\
\text { twice a week } \\
\text { (45 minutes) }\end{array}$ \\
\hline Croatia & Solfeggio & 6 years & Compulsory & $\begin{array}{l}\text { Two classes a week } \\
(45 \text { minutes })\end{array}$ \\
\hline Serbia & Solfeggio & 6 years & Compulsory & $\begin{array}{l}\text { Two classes a week } \\
\text { ( } 45 \text { minutes) } \\
\text { (first cycle of two year } \\
\text { Elementary music school - } \\
\text { three classes a week) }\end{array}$ \\
\hline
\end{tabular}

\subsection{The aims and tasks of Solfeggio teaching}

The aims of Solfeggio teaching are similar in the analyzed countries. The primary aim of teaching Solfeggio in all the above countries is to develop musicality and functional musical literacy through the pervasion of the educational and teaching process. Tasks primarily involve developing functional music literacy that is reflected in advanced music skills that are the link between transforming stored music content into a musical score and vice versa.

Rojko (2012: 16) states that when considering the tasks and objectives of Solfeggio teaching, it is important to take into account the following issues: The issue of musical abilities and the possibilities of their detection and evaluation; Questions of optimal organization of teaching; The issue of teaching methods, and in particular of some special methods of mastering intonation and rhythm; The issue of the use of teaching aids; The issue of teaching textbooks; The issue of monitoring and evaluating student work and progress, etc., all according to age and students' psychological and musical abilities.

\footnotetext{
${ }^{6}$ Nastavni plan i program osnovnog muzičkog obrazovanja i vaspitanja, 2010 ("Službeni glasnik RS” broj 72/09): https://www.msdjenko.edu.rs/download/plan_oms2010.pdf
} 
In the next paragraph, some of the tasks of teaching Solfeggio, emphasized within the curricula of all countries analyzed for this subject, are highlighted:

Development of reading, writing and comprehension of music and musical writing with the development of musical thinking; developing musical abilities (musical memory, ability to track melodic, harmonic and polyphonic flow); implanting sound performances and connecting them to an image, that is, images with sound through the acquisition of knowledge and skills; developing voice potential and proper intonative singing; developing a sense of rhythm, inner hearing, training for the analytical perception of tone relationships and their application; developing critical thinking; developing cognitive function through musical activities, developing verbal, emotional, logical-mathematical, spacial, musical, kinesthetic and interpersonal intelligence.

Prominent importance is given to getting to know the music literature and interpreting the basic elements of musical styles, as well as the independence of students and the development of their creative abilities, then developing the capacity of expression through music, both individually and in a group. Particular attention has been paid to developing the potential and satisfaction in the activities of musical creativity, improving the quality of life through the aesthetics of musical experience, developing musical taste and the ability to evaluate. In accordance with the requirements of the present, it is also important to become familiar with contemporary music technology and to develop a positive attitude towards continuous lifelong learning.

\subsection{Teaching Elements}

Outcomes of Solfeggio teaching are achieved through various activities that are an integral part of specific areas within the course (Table 2). In Slovenia, the area Snolfeggio involves mastering rhythms, meters, singing (solmization syllables in absolute height and tonal alphabet), developing musical memory and perception through dictation. Within the field of Performing and Analyzing Literature Examples, students become accustomed to aesthetically designing and interpreting selected examples from the music literature, developing performing and articulating skills, as well as the ability to play group music while playing Orf instruments. The area of Creative work involves the creation of musical content based on the acquired musical experience, ranging from short musical supplements, to the creation of accompaniment to selected musical examples, with continuous work on improvisation exercises. Listening involves developing analytical thinking, recognizing the theoretical and formative characteristics of what is heard, and learning about the aesthetic evaluation of a piece of music. Knowledge of Music Theory and Musical Form refers to music literacy, familiarization, understanding and use of musical concepts, familiarity with theoretical concepts and characteristics of musical instruments.

Learning outcomes of Solfeggio with Music Theory in Montenegro are realized through the following activities: Active Listening as a key process in the development of inner pitch aims at analytical understanding of music, within this area, examples from literature and dictation are cultivated. Expressive Performance plays an important role, first of all, because all the acquired knowledge is demonstrated through practical performance (singing, playing, tapping, music games) with the use of musical elements for expression (dynamics, tempo and character, articulation, agogic).

An important activity before performing is to analyze the musical example that will be performed. This activity empowers the student to express themselves publicly and 
confidently based on well-acquired information and experiences. Creativity involves introducing students to the basic technical processes in the process of making a piece of music, as well as the practical application of the acquired knowledge in the field of melodic, harmony and rhythm, in order to develop musical imagination and musicalcreative abilities. Information and Communication Technologies (ICT) refer to digital literacy of students using computers and tablets. Proper use of modern music technologies will enable the learner to apply their theoretical knowledge in a digital environment that is relevant to contemporary social trends. Music education based on new technologies to achieve the full educational capacity of each student is given a leading educational role and is a good preparation for the students in a modern digital work environment.

Curricula for Elementary Music and Dance Schools in Croatia list music literacy, scales, measure, intervals, chords, melody, rhythm, dictation, creative work and listening to music, and some of them can be equated with possible activities during the teaching class. The skill of true musical literacy is acquired through long-term and intense training and is not limited to the knowledge of music symbols. Musical literacy is reflected in the development of all elements of musicality, training the students to hear the score (before voice or an instrumental performance), and to imagine it while listening. Dictation must be present in Solfeggio teaching at all classes, from day one. Singing takes place in almost every activity in the Solfeggio teaching. Learning scales also requires their auditory recognition and performance, and is similar to learning intervals and chords, and performing dictation activities.

The basic teaching elements on which Solfeggio lessons in Serbia are based are melodic (singing and dictation), rhythm and music theory. In our teaching practice, the principle of the spiral curriculum is applied, which is also observed in the programs of countries in the region (Bruner, 1976). ${ }^{7}$ At different ages, the content of the course is approached in a new way in accordance with student developmental level, and thus the acquired knowledge and skills become more complex, are deepened and the level of expertise is increased. Melodic implies sight-singing (setting pitch, singing one-part melodic and polyphonic examples in diatonics, processing modulations, alterations, modal melodic lines and non-tonal contents) and dictation, which is unified with the setting of the melody and guarantees a dual direction of teaching - from score to reproduction and from the sound reception to the score (Vasiljević, 2006: 62). In addition to acquiring the ability to transfer an audio image into score, all elements of musicality and musical memory develop through oral and written dictations. Dictation is the prevailing way of practicing at all stages of music education. What changes is the complexity of the musical material, and the teacher's task in this regard is to select (or independently compose) dictations that are appropriate to the students' developmental level (Matoš, 2018). Rhythm, elements of rhythm, familiarity and interpretation of metric types in reading the score, mastering the tempo and agogic also cannot be separated from the melodic, while Theory of Music provides an understanding of the musical flow and understanding of the score.

\footnotetext{
${ }^{7}$ According to Bruner, the spiral curriculum signifies a repetition of key concepts, but with a deepening of layers of complexity and with different application. This phenomenon allows students to become familiar with concepts that would otherwise be "reserved" for later, after students have mastered fundamental principles that are often very theoretical and that may discourage students who are eager to apply what they are learning. Bruner, D. (1976) Proces obrazovanja. in: Kovač-Cerović Tinde [ur.] Psihologija u nastavi, Beograd: Savez društava psihologa Srbije
} 
Table 2 Teaching elements

\begin{tabular}{|c|c|c|c|}
\hline Slovenia & Montenegro & Croatia & Serbia \\
\hline Solfeggio & Performing & Music literacy & $\begin{array}{l}\text { Melodic } \\
\text { (perception, } \\
\text { singing, dictation) }\end{array}$ \\
\hline $\begin{array}{l}\text { Performing and analyzing examples } \\
\text { from the music literature }\end{array}$ & Creating & $\begin{array}{l}\text { Marks and } \\
\text { symbols }\end{array}$ & Rhythm \\
\hline Creating & Listening & Scales & Theory of music \\
\hline Listening & Musical games & Measure & \\
\hline \multirow[t]{6}{*}{ Knowledge of music theory and form } & Dance (choreography) & Intervals & \\
\hline & ITC & Melodic & \\
\hline & & Rhythm & \\
\hline & & Dictation & \\
\hline & & Creating & \\
\hline & & Listening & \\
\hline
\end{tabular}

\subsection{Methods}

Different approaches to the essence of Solfeggio teaching and the variety of pitch setting methods characterize the entire territory. In teaching practice, scale settings are most often present, through the theoretical interpretation of the position of degrees and half-steps, then intervals - through the processing of scale intervals, or free intervals which are then transferred into diatonic movements, and the settings of individual tones that can be transmitted and used to master the theoretical foundations of scale relationships and intervals (Drobni, 2008). The development of Serbian Solfeggio pedagogy in the 1970s followed the transition from a methodological path from tonic to absolute intonation with the use of alphabet and solmization, from interval, scale-interval, to the functional method, from learning rhythm on one line to rhythmic pronunciation, or parlato (Karan, 2006: 147148). Today in Serbia, the Roman way of absolute naming by solmization - absolute solmization - is dominant in performing melodies and perception, using the combined functional method created by combining Miodrag Vasiljevic's functional method based on folk tonal basics and some elements of the Elly Bašić method with classical harmonic and rhythmic bases of music education. The alphabetical method is used in cases of oral theoretical interpretation, during analysis and practical training. In parallel with solmization, in some parts of Vojvodina, the use of the Tonika-do method is present, influenced by the Kodaly school, and with an alphabetical mode of naming while singing (Drobni, 2008a).

Since Montenegro was a part of Serbia until the first decade of this century, the education system was developing and consolidating in accordance with the circumstances. This justifies the appearance of the same or similar methodological procedures within the teaching of Solfeggio. In Montenegro, the absolute naming of tones by solmization syllables is also used, and the basic pitch levels are set by Miodrag Vasiljevic's functional method, with adaptation to the Montenegrin climate through the use of the Montenegrin mother tongue (Marković, Ćoso-Pamer, 2016).

In Croatia, until the 1930s, the teaching of Solfeggio was mostly performed by absolute intonation methods. Due to the absence of regulations for the obligatory method of practicing intonation, new absolute and relative intonation methods, such as the functional method (Elly Bašić), which starts from the view that the awareness of the sense of tonality can be based only on the musical-psychological logic of the functions of 
degrees, are emerging (Ban, Svalina, 2013: 188). More recently, the use of the REA (relative and absolute) method in which intonation is set by fixing the relative and absolute pitch levels of formulas - short, catchy, and easily memorable tunes composed of seven to fifteen models that form the backbone of the REA method (Oliver, 2001: 8). The formulas are based on the phenomenon of remembering the initial tone of a model whose remainder is (very quickly) discarded over time. Formulas / models are intended for a particular problem, so relative formulas set the major, minor, whole-tone scales, modes, all tones in relation to tonics, and several tonics of related tonalities, while absolute formulas set absolute pitch levels of tones, intervals, chords and tonalities functionally related to the tone center.

In Slovenia, in the past two decades the relative method has been replaced by the absolute tonal method, which is a valid part of the curriculum at the lower educational level, while at the upper level the basic use of this method leads to the transition to the interval method (with absolute solmization) (Zadnik, 2019). In Slovenia, in addition to the promotion of the REA method through seminars, the Willems method has recently become popular, by the author of Belgian origin and student of Dalcroze method Edgar Willems, after whom the method is named. According to Simon Stancir (Stancir, 2011), it is based on the principle that music education has a rational basis to respond to the psychological development of persons. In this sense, the method focuses on learning the basic elements of music and viewing music as an integral part of the nature of human beings (Jovanović, 2018). Edgar Williams' methodological system enables a coherent transition from instinctiveness to conscious action and mastery of the automatism needed in the field of music education. This method takes into account the development of hearing in its physiological, affective and mental aspects. At the same time, it encourages the development of a sense of rhythm that comes from a person's own energy. Songs play an important role, especially interval learning songs. First, relative, then absolute and combined naming is applied. ${ }^{8}$

The variety of methodological procedures has been maintained to this day. It is a common view that the teacher should be familiar with the different musical methods, their advantages and disadvantages, and on the basis of knowledge of these methods, apply the one that will bring the greatest progress in acquiring musical abilities (Rojko, 2012). The historical development of the pedagogy of Serbian music literacy speaks in favor of the fact that the solution of one of the most difficult tasks of Solfeggio teaching - conscious comprehension and sound realization of a musical notation, should not be sought by all means in foreign models. In this context, a number of domestic Solfeggio educators advise that mastering not only musical writing but also certain melodic and rhythmic patterns is approached through the song-model of Miodrag Vasiljevic (Drobni, 2008). In his functional method of singing on folk grounds, Miodrag Vasiljevic applied models, folk tunes, and adapted their initializations to the solmisation syllables, with several song-models given for each syllable, recognizing the importance of a large experiential sound fund for new learning. Several examples for each problem will create sound deposits in the minds of students, and, by pervading multiple methodical actions, the student is allowed to choose an association, thereby achieving individualization of the teaching process. In this way, by mastering small

\footnotetext{
${ }^{8}$ Edgar Willems Music Center (Edgar Willems) is a private music school in Ljubljana founded on the pedagogical principles of renowned music educator Edgar Willems. It is the first music school to successfully introduce to Slovenian territory two publicly recognized programs that are different from the national curriculum for music schools. Since 2002, it has been operating in Ljubljana and, besides the Bled Music Center Do re mi, is the only such music school in Slovenia: http://willems.si/zivljenjepis/znacilnosti-willemsovega-pristopa/
} 
forms, Solfeggio guides us from conception through cognition to comprehension towards acquiring, understanding and developing musical thinking, which is considered the culmination of cognitive activities. Understanding, as the inclusion of the new and the unknown in the circle of the old and the known, leads to knowledge, which must be permanent and functional in order to precede thought - the thought process of establishing functional connections and relationships.

\subsection{Student achievement evaluation}

Knowledge and the process of knowledge acquisition are accompanied by different evaluation procedures that ensure constant monitoring of the achievement of the prescribed goals, outcomes and standards of achievement of students. Through pedagogical assessment activity, the attitude towards learning and knowledge is expressed, motivation for learning is stimulated and the student is trained for an objective assessment of other students' and their own achievements, developing a system of values. In doing so, the motivation to learn should not be external, directed at the assessment itself, but at the students` development, progress and success. Teachers are expected to constantly and comprehensively monitor students' musical development and achievement through various teaching activities. A teacher who is highly familiar with the opportunities and educational needs of the students is responsible for compiling and processing targeted exercises with carefully selected music patterns, applying adequate examples from the music literature, implementing music activities, and subsequently, for formative and summative evaluation of student achievement (Matoš, 2018).

Evaluation of student achievement in music schools in Slovenia is regulated and is carried out in accordance with the Rulebook for Assessment of Knowledge and Progress of Students in Music Schools. ${ }^{9}$ Achievements of musical ability, skills and knowledge are continuously recorded and evaluated. By the end of the evaluation period, the evaluations are summed up in numerical assessments in accordance with this Rulebook. According to article two of this rule, the teacher tests the students` knowledge taking into account the knowledge and understanding of the learning materials, the ability to analyze, synthesize and interpret, master practical skills and creative use of knowledge, use different ways of testing and assessing knowledge in accordance with the content of learning - enabling the student to be self-critical and encourage self-assessment, while respecting the personal integrity of the student. The teacher checks the knowledge before, during and after the transfer of new learning contents (Article 3). In the teaching of Solfeggio, students' oral responses, written and project papers are evaluated. Students' knowledge is assessed by the teacher in question, and by the examination board for the annual and remedial exams.

In Montenegro, evaluation is carried out on the basis of the Law on Vocational Education $^{10}$, and is further specified in the subject program for the subject Solfeggio with Music Theory. ${ }^{11}$ The subject program stipulates that the greatest importance in the assessment should be given to the area in which the student possesses the greatest abilities. This program also sets up basic criteria on which the final grade of students is based, namely:

\footnotetext{
${ }^{9}$ Pravilnik o preverjanju in ocenjevanju znanja ter napredovanju učencev v glasbenih šolah, 2016: http://pisrs.si/ Pis.web/pregledPredpisa?id=PRAV5180)

${ }^{10}$ Objavljen u "Sl. listu RCG", br. 64 od 28. novembra 2002, 49/07, "Sl. listu Crne Gore", br. 45 od 4. avgusta 2010, 39/13

${ }^{11}$ Predmetni program Solfeđo sa teorijom muzike, Zavod za školstvo, 2018
} 
- $70 \%$ student participation activity during the year;

- $15 \%$ written final exam (melodic and rhythmic dictation, music theory);

- $15 \%$ oral final exam (melodic, parlato, and rhythmic exercise).

In Croatia, the assessment and monitoring of students is carried out under sections 50, 51, 52 and 53 of the Primary Education Act. ${ }^{12}$ This law specifies commission evaluation for art school students as follows: the committee consists of three members - a subject teacher and two expert lecturers of the same subject, that is, of the same type of instrument. Elementary art schools that do not have a sufficient number of teachers of the same subject, or the same type of instrument, establish a commission in cooperation with the nearest elementary art school.

Assessment of students' knowledge in Serbia is also governed by the Rulebook on Assessment of Students in Primary Education from 2013. ${ }^{13}$ The novelty in this rulebook in relation to the countries analyzed is a clear definition of the general principles of education and upbringing that should be followed by assessment. The principles of evaluation, within the meaning of this Rulebook, are: 1) objectivity in evaluation according to established criteria; 2) the relevance of the assessment; 3) use of various assessment techniques and methods; 4) fairness in evaluation; 5) regularity and timeliness in evaluation; 6) evaluation without discrimination and separation on any basis; 7) appreciation of individual differences, needs, ages, students' previous achievements and current conditions in which the assessment takes place.

Formative assessment, for the purposes of this rulebook, is the regular review of achievement and monitoring of students' behavior during mastering the school's curriculum, contains feedback and recommendations for further progress and, as a rule, is recorded in the pedagogical documentation of teachers, in accordance with this rulebook. Summative assessment, for the purposes of this Rulebook, is the evaluation of student achievement at the end of the program unit or for the subject and mastery classification period. Grades obtained by summative assessment are, as a rule, numeric and are entered in the prescribed records of educational work (diary). They can also be entered in pedagogical documentation.

In all analyzed countries, the rulebooks determine the publicity of the assessment, which must be ensured by presenting the objectives and content of the course in each assessment period, informing students, parents and guardians of the criteria, manner, procedure and dynamics, and the timetable for the assessment. The teacher should keep a record of the student's success, that is, in the assessment process, to collect and record data on the student's achievement, progress and development in the prescribed records and his / her pedagogical documentation.

According to the rulebook on grading students in primary education in Serbia, knowledge is evaluated by descriptive and numerical assessment. In the other countries analyzed, knowledge is valued solely by numerical evaluation. The criteria for numerical grading of student achievement in all the above countries are the same, and in Table 3 we will outline the united criteria based on the review and analysis of all the countries mentioned. Numerical grades evaluate students' knowledge on a scale of 1 to 5 . The grades are: insufficient (1), sufficient (2), good (3), very good (4), excellent (5). Grade (1) is negative, other grades are positive, i.e. transient. A negative grade is given to a student who does not meet the minimum standards of knowledge set by the curriculum.

\footnotetext{
${ }^{12}$ MZOŠ, 2010 http://www.gsjh.hr/wp-content/uploads/2017/12/Nastavni_PP_predskolskog_i_osnovnog_obrazovanja za_glazbene_i_plesne_skole.pdf

${ }_{13}$ Pravilnik o ocenjivanju učenika u osnovnom obrazovanju i vaspitanju, 2013: http://www.mpn.gov.rs/wpcontent/uploads/2015/08/\%D03.pdf
} 
Table 3 Numerical evaluation criteria

\begin{tabular}{ll}
\hline Grade & Description \\
\hline Excellent (5) & $\begin{array}{l}\text { The student interprets the processed material independently, makes very significant } \\
\text { progress in mastering the course syllabus, excels in engagement, success and } \\
\text { creativity, adheres to the given topic and perceives the essence of the content. }\end{array}$ \\
The student independently interprets the processed material accurately, makes \\
significant progress in mastering the course syllabus, with a high degree of \\
engagement, adheres to the given topic and perceives the substance of the content. \\
The student, with the help of the teacher, accurately interprets the processed \\
material, makes progress in mastering the course syllabus, but lacks clarity in \\
expression, does not fully perceive the substance of the content. \\
The student makes minimal progress in mastering the course syllabus and strives, \\
with the help of the teacher, to interpret the material as accurately as possible, \\
shows no interest in creative expression, but responds to the encouragement of \\
the teacher, partially completes the tasks assigned.
\end{tabular}

\section{CONCLUSION}

The musical-pedagogical discipline of Solfeggio, as a basis for the development of functional musical literacy and musical thinking, should encourage the development of musicality on the path of individual musical development. In addition to developing and deepening musical hearing and musicality, this subject promotes aesthetic sensitivity, musical taste, the ability to evaluate musical works and become accustomed to the use of modern music technology in accordance with the progress of time. Musical literacy is deepened and enhanced through the various elements of work represented in teaching practice. By reviewing and analyzing the curriculum for the subject of Solfeggio in Serbia and several selected countries, we wanted to establish the development status of the curriculum in question, as well as to point out certain curricular areas that, following the model of some countries, should be updated.

The differences in the curricula are most visible in the organization of teaching, where we refer to the practice of harmonizing general and music education, similar to Montenegro, which could have positive effects in our country and in the surrounding countries. Teaching areas, although differently conceptualized, in the analyzed countries focus on the same goal, which is to develop musicality and functional musical literacy through the intersection of the music education and the educational process. In terms of methodical solutions, Serbia has its own pedagogical style, built and based on the experience and knowledge of domestic and foreign pedagogical achievements. In addressing the teaching problem, foreign models should be accepted with the support of tradition and the preservation of primal tonal foundations, as an important part of the musical heritage of a nation. The principle of student achievement evaluation is in line with these countries, but it has been found that only Slovenia and Montenegro have a Rulebook for assessing students' knowledge and progress in music, i.e. vocational schools, while in Croatia and Serbia this segment of evaluation takes place according to the Rulebook on Student Assessment in primary education. In the coming period we should think of a closer definition of these curricular areas modeled on neighboring countries. Analyzing the curricula for the subject of Solfeggio for Elementary Music Education we come to the conclusion that Serbia has laid a 
good foundation for the development of the subject curriculum, but also that some curriculum areas modeled on some countries should be modernized. In a methodological sense, however, the countries of the region could look at the Serbian methodical practice, which emphasizes the importance of establishing the basic tones and tonal functions for understanding and raising awareness of any teaching problem. The paper is a starting point for considering the overall developmental status of the curriculum for the subject of Solfeggio and for a more detailed analysis and comparison of all educational levels, because only by looking at modern aspirations in vocational education and training can we somewhat anticipate their further development.

\section{REFERENCES}

Aleksendrić, B., (2009), "Shvatanja i pristupi teoriji i praksi kurikuluma", Nastava i vaspitanje 3, Vol. 58: pp. 331-347. https://www.pedagog.rs/wp-content/uploads/2009/09/shvatanje-i-pristupi-teoriji-i-praksikurikuluma.pdf

Ban, M. and Svalina, V., (2013), "Različiti pristupi svladavanju intonacije u nastavi solfeggia", Život i škola: časopis za teoriju i praksu odgoja i obrazovanja 59, 30: pp. 172-191. https://www.academia.edu/ 9962424/Razli\%C4\%8Diti_pristupi_svladavanju_intonacije_u_nastavi_solfeggia_Different_Approache s_to_Mastering_Intonation_in_Solfeggio_Lessons

Bruner, D., (1976), "Proces obrazovanja", In: Kovač-Cerović, T. (ed.) Psihologija u nastavi, Savez društava psihologa Srbije, Beograd

Cvetković-Crvenica, J. and Jovanović, M., (2018), "Possible aspects of vocal interpretation in solfeggio teaching", In: Marković, V. and Martinović-Bogojević, J. (ed.) Music Pedagogy Challenge, Inspiration and Creation, First international symposium on music pedagogy, Cetinje UDK 784.9:371.3 https://indd.adobe.com/view/ec780421-2452-4a68-aeda-f4787c72967c

Cvetković-Crvenica, J. D., (2017), "Inner pitch and reception in contemporary pedagogy: Fostering and development". Godišnjak Pedagoškog fakulteta u Vranju, 8(2): pp. 283-298. doi:10.5937/gufv1702283C

Drobni, I., (2008), Metodičke osnove vokalno-instrumentalne nastave, Zavod za udžbenike, Beograd. ISBN 978-86-17-15673-0

Drobni, I., (2008a), "Tonalno - apsolutno, ili u potrazi za metodičkim konsenzusom", Nastava $i$ vaspitanje 1, Vol. 57: pp. 30-42. UDK-37.015.036 https://www.pedagog.rs/wp-content/uploads/2016/05/tonalnoapsolutno.pdf

Hebib, E. and Spasenović, V., (2011), "Školski sistem Srbije - stanje i pravci razvoja", PEDAGOGIJA LXVI, 3: pp. 373-383. https://www.researchgate.net/profile/Vera_Spasenovic/publication/ 277122486_School_system_of_Serbia_State_and_directions_of_development/links/564ca47808ae7ac727 e20458.pdf

Jovanović, M., (2018), Inkluzivni pristup nastavi solfeđa u prvom ciklusu šestogodišnjeg osnovnog muzičkog obrazovanja $i$ vaspitanja, Neobjavljen Završni rad na Master akademskim studijama, Fakultet umetnosti, Univerzitet u Nišu.

Jurić, V., (2005), "Curriculum Of Contemporary School", Pedagogijska istraživanja 2, 2: pp. 185-186. https://hrcak.srce.hr/139326

Karan, G., (2006), "Music education in Serbia" In: Karan, G. (ed.) Movement in Music and in Performing Arts, 8th Pedagogical Forum, Belgrade

Matijević, M., (2010), "Između didaktike nastave usmjerene na učenika i kurikulumske teorije", In: Ivanšić, I. (ed.), Zbornik radova Četvrtog kongresa matematike, Zagreb

Matoš, N., (2018), Kurikulumski pristup oblikovanju profesionalnoga glazbenog obrazovanja, doktorski rad, Sveučilište u Zagrebu, Filozofski fakultet, Zagreb. http://darhiv.ffzg.unizg.hr/id/eprint/10755/1/ Matos_Nikolina.pdf

Marković V. and Ćoso-Pamer, A., (2016), Muzički koraci 1 - priručnik za prvi razred osnovne muzičke škole, Zavod za udžbenike i nastavna sredstva, Podgorica. https://www.zuns.me/sites/default/files/ prirucnici/pdf/muzick\%20i\%20koraci_1.pdf 
Oliver, O., (2001), "REA", Theoria 3, 3: pp. 7-10. http://hdgt.hr/wp-content/uploads/sites/184/2014/ 10/Theoria_03.pdf

Pavić, B., (2017), Kompetencijski profil nastavnika solfeggia, diplomski rad, Sveučilište Josipa Jurja Strossmayera u Osijeku, Umjetnička akademija u Osijeku, Odsjek za glazbenu umjetnost, Diplomski studij glazbene pedagogije. https://repozitorij.uaos.unios.hr/islandora/object/uaos\%3A323/datastream/ $\mathrm{PDF} / \mathrm{view}$

Pekeč, K., (2011), "Miomir Despotović, Razvoj kurikuluma u stručnom obrazovanju: pristup usmeren na kompetencije [Prikaz knjige]", Andragoške studije, broj 1: pp. 207-212. UDK 374.7:331]: 001.101(049.32); ID: 183236876 http://www.as.edu.rs/search?n=2011-1\&l=sr

Previšić, V., (2007), "Pedagogija i metodologija kurikuluma", In: Previšić, V. (ed.) Kurikulum: teorije, metodologija, sadržaj, struktura, Školska knjiga, Zagreb

Rojko, P., (2012), Psihološke osnove intonacije i ritma, Muzička akademija Sveučilišta u Zagrebu, Zagreb. https://bib.irb.hr/datoteka/567762.P._Rojko_Psiholoke_osnove_intonacije_i_ritma.pdf

Stancir, J. S., (2011), Estudio de los parámetros del método Willems en las canciones más solicitadas en las radios juveniles, Final thesis, Universidad de San Carlos de Guatemala, Escuela de ciencias de la comunicacion. http://biblioteca.usac.edu.gt/tesis/16/16_0829.pdf

Sučević, V. and Srdić, V., (2012), "Struktura novog kurikuluma u funkciji evropskog koncepta kvalitetnog osnovnog obrazovanja - otvaranje prostora za autonomiju škola i nastavnika ", Sinteze, br. 1: pp. 29-49. UDK 37.014.5 371.214 https://scindeks-clanci.ceon.rs/data/pdf/2217-902x/2012/2217-902x1201029S.pdf

Vasiljević, Z., (2006), Metodika muzičke pismenosti, Zavod za udžbenike i nastavna sredstva, Beograd. ISBN 86-17-13555-7.

Zadnik, K., (2019), Nauk o glasbi v slovenski glasbeni šoli Med preteklostjo, sedanjostjo in prihodnostjo, Univerza v Ljubljani, Filozofska fakulteta, Univerza v Ljubljani, Akademija za glasbo, Ljubljana. DOI: 10.4312/9789610601593 https://e-knjige.ff.uni-lj.si

\section{KOMPARATIVNA ANALIZA KURIKULUMA ZA PREDMET SOLFEĐO (OMŠ) U SLOVENIJI, CRNOJ GORI, HRVATSKOJ I SRBIJI}

Rad se bavi upoređivanjem kurikuluma za predmet solfeđo u Srbiji i nekoliko odabranih zemalja. Na temelju postojećih podataka, upoređena je organizacija nastave solfeđa u Srbiji $i$ pojedinim državama regiona. Kurikulum je analiziran u pogledu strukture, ciljeva i sadržaja predmeta, nastavnih metoda i vrednovanja učeničkih postignuća. Prikazom i analizom kurikuluma želeli smo da ukažemo na njihove (ne)podudarnosti, prednosti i mane, te na putokaze budućeg razvoja u vidu osavremenjivanja nekih područja kurikuluma po uzoru na druge zemlje.

Ključne reči: solfeđo, nastava, muzička pedagogija, kurikulum. 